$\underline{\text { articles }}$

\title{
A New Perspective on the Perceived Benefits of a Science Park Location: Results From an fsQCA Analysis
}

\author{
Vicent Clemente-Císcar ${ }^{1}$, , Rosa M. Yagüe-Perales ${ }^{1}$ b , Isidre March-Chordà ${ }^{c}$ \\ 1 Faculty of Economics, University of Valencia \\ Keywords: innovation, science parks, fsqca \\ https://doi.org/10.53703/001c.32310
}

\section{Journal of Small Business Strategy}

Vol. 32, Issue 1, 2022

\begin{abstract}
Science Parks (SPs) have become a widely spread mechanism of global innovation. An assessment of SPs generally uses performance indicators, but perceptual measures are also recommended because of their capacity to identify specific objectives more distinctly among different firms.

This study explores the relationship between the tenant's profile and the perceived benefits of being located in a Science Park. The presentation of new evidence on the perceived value of the SP facilities and services would contribute to increasing the effectiveness and overall performance of the SPs and that of their wide range of tenants. An empirical study is conducted on a sample of 29 firms located in the University of Valencia Science Park (PCUV).

A Qualitative Comparative Analysis (QCA) is applied to our survey in order to identify various combinations of causal conditions, namely linking the attributes that define the firm's profile (performance, age and technology level) to different possible perceived benefits of being in a science park.

Our results reveal that to be a firm with a relatively low economic performance is a necessary condition for being located in a science park in search of a more fluid access to funding. In addition, we find several combinations of sufficient conditions for each one of the three factors affecting location decisions: proximity to a university, availability of funds, and agglomeration effects.
\end{abstract}

\section{INTRODUCTION}

Science Parks (SPs) have become a widespread mechanism around the world for the promotion of innovation, technology transfer and regional economic development. Beyond the macro and policy objectives, at the micro-level, the attractiveness of SPs to firms stems from being able to share facilities and services, their proximity to research bodies, and better conditions for knowledge transfer (Ferrara et al., 2014; Ng et al., 2020).

Previous studies have attempted to assess the impact of SPs using key performance indicators, such as employment (Colombo \& Delmastro, 2002; Ferguson \& Olofsson, 2004; Lindelöf \& Löfsten, 2002), innovative outputs (Fukugawa, 2006; Vedovello, 1997; Westhead, 1997) and economic results (Díez-Vial \& Fernández-Olmos, 2017; Lee \& Yang, 2000; Lindelöf \& Löfsten, 2002; Vedovello, 1997). Most of these studies follow a partial approach that limits them from properly reflecting all potential benefits that tenants may receive from their SP residence. The extant literature agrees on the promotion of networking and collaboration between firms; however, little evidence is found for increased economic output (Albahari et al., 2010).

Furthermore, many of the advantages contributed to SPs as suggested by the literature, such as image or credibility, do not necessarily lead to enhanced firm performance. Further research is therefore needed to gain a more precise assessment of the effectiveness and contribution of SPs to the economic development of the host territory.

The wide variety of agents usually hosted in the SP location hold diverse objectives and expectations. This implies that, apart from performance indicators, perceptual measures should also be present in any assessment analysis because of their capacity to grasp specific objectives more distinctly among different firms. Perceptual measures, such as perceived value and satisfaction, are believed to complement the performance measures and reveal a more detailed picture of the actual benefits provided by SPs (Lecluyse et

\footnotetext{
a Av. dels Tarongers, s/n, 46022 Valencia, Spain, vicent.clemente@fundacions.uv.es

b Av. dels Tarongers, s/n, 46022 Valencia, Spain, rosa.m.yague@uv.es

c Corresponding author:

Isidre March-Chordà (isidre.march@uv.es)
} 
al., 2018; Lecluyse \& Knockaert, 2020; Ng et al., 2019).

Previous studies on tenant firms' perceived benefits of SPs include location for reasons specific to the firm (Van Dierdonck et al., 1991), perceived benefits of the management function of SPs (Westhead \& Batstone, 1999), the location (Dettwiler et al., 2006; Westhead \& Batstone, 1998) and the profit gained from networking and collaboration between firms (Ng et al., 2019).

Although the need to consider the peculiarities of each park seems obvious, Albahari et al. (2017) highlight that most studies on SPs have so far focused on homogeneous effects of on-park location, with a tendency to implicitly assume similar effects on all tenant firms. However, categories of tenants present in SPs are heterogeneous and include both private organizations (i.e., start-ups, spin-offs, small-to-medium enterprises, large firms, or multinationals) and public bodies (research institutes and higher educational institutions) with different interests and expectations (Hansson et al., 2005). In addition, the needs and priorities of these firms will largely differ, depending on their stage of development (Ferguson \& Olofsson, 2004).

The inconclusive and even conflicting results regarding the impact of SPs probably reflect the diversity of benefits the tenant firms obtain from being onsite (Vasquez-Urriago et al., 2015). In fact, there is little evidence to date that clarifies how the different typologies of tenants take advantage of the on-park location, and how they perceive the benefits of being located in such facilities.

From the users' point of view, an essential first step is to better understand how SPs create value for their tenants (Albahari et al., 2019). However, the stream of research which focuses on the perception from the user side of SPs is very limited, so any new evidence on this topic is a welcome contribution to increasing the effectiveness and overall performance of the SPs and that of their wide range of tenants. This study is intended to help meet this need by exploring the relationship between the tenant's profile and the benefit perceived from being located in a science park.

Firms located in SPs may differ in their performance, technology and age. By examining different configurations of these attributes, we can detect whether these reflect the perception of benefits offered by SPs. From this consideration, two main research questions emerge:

a) Which perceived benefits typically provided by the SP are more attractive to the different typologies of tenants?

b) To what extent do certain key attributes of the tenant firms influence their perception of the benefits of the science park and their motivations to be located there?

In order to answer these research questions, an empirical study is conducted on a sample of 29 firms located in one of the most active science parks in Spain: the University of Valencia Science Park (PCUV), which has been in operation since 2008 and, since then, has hosted more than 200 innovative firms. The firms surveyed were classified according to three common criteria used to define New-technology-based firms (NTBFs) and other typical SP tenants: performance, age, and technological development (Storey $\&$ Tether, 1996). CEOs of these firms were asked their reasons for choosing to be located in the SP and the benefits directly derived during the tenancy. The application of fuzzyset qualitative comparative analysis (fsQCA) allowed us to identify various combinations of causal conditions, namely the attributes that define the firm's profile (performance, age, and technology level), linked to different possible perceived benefits from being located in the SP.

Our findings shed light on the value that SPs bring to the different types of tenant firms, and lead to several contributions: first, an exploration and identification of the ways SPs create value for their different kinds of tenants; second, the presentation of new evidence on the motivations and perceived benefits that lead firms to choose to be located in SPs; and third, the application of the emerging fsQCA technique as a pioneering approach in the field of business incubators and science parks.

The study continues with an analysis of the literature on the potential benefits SPs offer to their tenants. We then present a description of the data collection and methodology, followed by the results and discussion of the main findings. The study ends with the conclusions section, which also considers limitations, implications for management and suggestions for future research.

\section{THEORETICAL FRAMEWORK}

The decision of a firm to be located in a science park is believed to be strongly dependent on the benefits perceived by tenants and the complementarities they can gain from the SP (Ferguson \& Olofsson, 2004; Wright et al., 2008). However, the community of firms located in SPs is heterogeneous in terms of profile, expectations and needs and, consequently, not all tenants benefit equally from the SP residence (Gwebu et al., 2019; Lecluyse et al., 2018; Vasquez-Urriago et al., 2015). SPs that intend to attract a wide variety of firms are expected to provide different types of support, depending on the tenant's development stage and attributes (Ferguson \& Olofsson, 2004). According to Albahari et al. (2019), the business support provided by SPs can be divided into two components: a configuration-oriented component, and a process-oriented component. The former refers to the static design of the business support, and the latter to the active, hands-on support provided by the science park's management. More details of these components are discussed below.

\subsection{The configuration-oriented business support of science parks}

University science parks are multi-tenant areas, located in and around university campuses, and provide physical facilities and services, as well as access to laboratories, government subsidies, customers, suppliers and employees, which may not be available in other locations (Phan et al., 2005; Westhead \& Storey, 1995).

Although there is no universally accepted definition of SPs (Löfsten \& Lindelöf, 2005), the concept of SPs generally involves three components:

1. A concentration of high-tech industries and specialized service centres.

2. The existence of at least one university or technology institute with which tenant firms may maintain some form of formal link: and

3. The promotion of knowledge transfer, such as tacit 
knowledge and technology, to tenant organizations.

The number of SPs operating in the world has increased significantly in recent years. The International Association of Science Parks and Areas of Innovation (IASP) estimates that there are around 1,200 active science and technology parks throughout the world (Amoroso, SaraLink \& Wright, 2019). Diversity among these parks is substantial, and differences in organizational structure and SP objectives complicate the development of a unified conceptual framework for SP research (Mian et al., 2016).

Albahari et al. (2019) point out a significant divergence among SPs with regard to value creation for their tenants. Based on Autio \& Klofsten (1998), they identified two main components of business support offered by SPs:

- A process-oriented component; related to the services and activities offered to tenants, such as incubation, training, and networking activities for firms.

- A configuration-oriented component; comprising a static business support design including provision of appropriate infrastructure, building a strong identity for the SP, availability of funding, and proximity to a major university.

The portfolio of support services offered by SPs can be grouped according to these two components. The processoriented business support is more idiosyncratic and specific to the context, characteristics, and objectives of each SP, whereas the configuration-oriented support is more generalist and common to any model of SP. This study adopts this second perspective since it can better reveal the benefits perceived by firms that choose to be located in SPs and can yield replicable results and conclusions for the majority of SPs. This perspective derives three main components or potential benefits that the tenant firms might perceive from being located in the SP:

- Proximity to a university (to facilitate technology transfer and knowledge spillovers).

- Amplification of firms' agglomeration effects (building a strong identity, and increasing the number of firms and the synergies between tenants); and

- Availability of funds (to facilitate access to funds).

Being located in a university science park usually offers the firm a privileged access to valuable university resources, such as facilities and labour force (Dettwiler et al., 2006; Löfsten \& Lindelöf, 2005). Cooperation with university staff may provide access to the latest research, resulting in the development of more innovative products (Audretsch et al., 2005; Díez-Vial \& Fernández-Olmos, 2015).

In terms of agglomeration effects, the spatial proximity among firms and universities converts the SP into an environment that is conducive to innovation, enhancing both formal and informal knowledge and information flows between the organizations housed onsite (Guo \& Verdini, 2015). Tenant firms have the opportunity to engage in synergistic activities and start trading quickly without large overheads, while also benefitting from credibility, endorsement, and further opportunities for networking (Felsenstein \& Felsenstein, 1994).

Funding is one of the major difficulties faced by technology-based start-ups (Storey \& Tether, 1998). In this sense, being located in a science park might encourage the attraction of external capital (Löfsten \& Lindelöf, 2003). So, in addition to gaining access to a wide range of services and good-quality accommodation at affordable prices, firms may be attracted to SPs to take profit from the better financial options (Kihlgren, 2003; Radosevic \& Myrzakhmet, 2009), arising from the park's assumed ability to convince public and private bodies to provide financing for tenant firms (Kihlgren, 2003). The clustering effects that SPs can trigger are believed to appeal to venture capitalists who are attracted by the incubation facilities, as well as the credibility, advice and guidance provided by the SP management team (McAdam \& McAdam, 2008).

The following table summarizes a list of relevant studies dealing with the three components of the configurationoriented business support approach (Table 1). 
Table 1.

\begin{tabular}{|c|c|c|c|c|c|c|c|c|c|}
\hline \multirow{2}{*}{$\begin{array}{l}\text { SP CONFIGURATION-ORIENTED } \\
\text { BUSINESS SUPPORT (Albahari et al., } \\
\text { 2019) } \\
\text { Previous literature }\end{array}$} & \multicolumn{3}{|c|}{ PROXIMITY TO UNIVERSITY } & \multicolumn{3}{|c|}{$\begin{array}{c}\text { AMPLIFICATION OF } \\
\text { AGGLOMERATION EFFECTS }\end{array}$} & \multicolumn{3}{|c|}{ AVAILABILITY OF FUNDS } \\
\hline & $\begin{array}{l}\text { Access to talent } \\
\text { (I): students } \\
\text { /graduated }\end{array}$ & $\begin{array}{l}\text { Access to } \\
\text { talent (II): } \\
\text { researchers }\end{array}$ & $\begin{array}{l}\text { University } \\
\text { facilities } \\
\text { equipment }\end{array}$ & $\begin{array}{c}\mathrm{SP} \\
\text { facilities }\end{array}$ & $\begin{array}{l}\text { Prestige } \\
\text { / Image }\end{array}$ & Network & $\begin{array}{l}\text { Access } \\
\text { public } \\
\text { funds }\end{array}$ & $\begin{array}{l}\text { Access } \\
\text { venture } \\
\text { capital }\end{array}$ & $\begin{array}{l}\text { Rental subsidies, } \\
\text { cost of } \\
\text { accommodation }\end{array}$ \\
\hline (Audretsch et al., 2005) & $\mathrm{x}$ & $\mathrm{x}$ & & & & & & & \\
\hline (Bakouros et al., 2002) & & & & $\mathrm{x}$ & $\mathrm{x}$ & $\mathrm{x}$ & & & \\
\hline (Dettwiler et al., 2006) & $\mathrm{x}$ & $\mathrm{x}$ & & $\mathrm{x}$ & & $\mathrm{x}$ & & & \\
\hline (Felsenstein \& Felsenstein, 1994) & & & & & $\mathrm{x}$ & $\mathrm{x}$ & & & \\
\hline (Ferguson \& Olofsson, 2004) & $\mathrm{x}$ & $\mathrm{x}$ & & & $\mathrm{x}$ & $\mathrm{x}$ & & & \\
\hline (K. F. Chan \& Lau, 2005) & & $\mathrm{x}$ & $\mathrm{x}$ & & & & & & $\mathrm{x}$ \\
\hline (Kihlgren, 2003) & & & & $\mathrm{x}$ & & & $\mathrm{x}$ & $\mathrm{x}$ & $\mathrm{x}$ \\
\hline (Koh et al., 2005) & & $\mathrm{x}$ & $\mathrm{x}$ & & & & & & \\
\hline (Lindelöf \& Löfsten, 2002) & $\mathrm{x}$ & & & & & $\mathrm{x}$ & & & \\
\hline (Löfsten \& Lindelöf, 2003) & & & & & & $\mathrm{x}$ & & $\mathrm{x}$ & \\
\hline (McAdam \& McAdam, 2008) & & & & $\mathrm{x}$ & $\mathrm{x}$ & & & $\mathrm{x}$ & \\
\hline (Radosevic \& Myrzakhmet, 2009) & & & & & $\mathrm{x}$ & & $\mathrm{x}$ & $\mathrm{x}$ & $\mathrm{x}$ \\
\hline (Salvador, 2011) & & & & $\mathrm{x}$ & $\mathrm{x}$ & & & & \\
\hline (Yang et al., 2009) & & $x$ & $\mathrm{x}$ & & & $\mathrm{x}$ & & & \\
\hline
\end{tabular}

Source: compiled by the authors 
The most significant variables highlighted by the literature and stated in Table 1 are in line with those noted by $\mathrm{Ng}$ et al. (2019). These include the following list of benefits perceived by tenant firms in SPs: (1) knowledge sharing and collaboration; (2) proximity of university; (3) proximity of firms in similar sectors; (4) proximity of markets and customers; (5) liveability of the site; (6) image and prestige of the site; and (7) cost of the accommodation and services. The variables selected for inclusion in our model of analysis are extracted from this list.

\subsection{Science park tenant firms}

There is a growing stream of research that connects the location choice with the added-value perception of the business support provided by the SP (Ferguson \& Olofsson, 2004; Wright et al., 2008). For instance, (Löfsten \& Lindelöf, 2003) claim that further research on the characteristics and performance of tenant firms is the best way to properly understand and measure the actual added value provided by science parks. However, the shortage of studies addressing the contribution of SPs to their tenants' performance highlights the need to further explore the pattern of benefit perception by different categories of tenant firms.

Based on the configuration-oriented component approach, this study aims to meet this need by providing new evidence on the relationship emerging between the different tenant profiles and the perceived benefit from the SPs' facilities and services. In order to identify different typologies of tenant firms, we focus on the firm-level input factors, which generally include firm age and size, origin, and technological and financial resources (Lecluyse et al., 2018). We empirically test our model with a sample of firms located in the PCUV, which are classified according to three common criteria used to define NTBFs and other SP tenants: performance, technology, and age (Storey \& Tether, 1996). These attributes are described below.

Starting with performance, SPs host a wide variety of tenants, ranging from large corporations to university spinoffs. Based on a survey of 82 SPs pertaining to 16 European countries, Ng et al. (2017) identified the different typologies of resident organizations usually located in SPs, and their frequency of presence. These included NTBFs, and corporate or university spin-offs. Lindelöf \& Löfsten (2002) assessed the value-added contributions of firms located in SPs and off-site through management and financial measures, including employment, sales growth and profitability. They expected that NTBFs in science parks would perform better than the average firms. Díez-Vial \& Fernández-Olmos (2017) concluded that on-park firms tend to outperform the others, especially during periods of economic downturn, whereas Ferguson \& Olofsson (2004) attributed the better performance in the science park group to the presence of a few high-performing firms.

Thus, lower-performing firms might seek to be located in science parks to benefit from these facilities, attracted by these better prospects highlighted in the literature. This review supports the inclusion of a firm's performance as one of the key firm-level input factors. This variable is measured in our model through the annual average growth of employment and sales, in line with Lindelöf \& Löfsten (2002)and
Díez-Vial \& Fernández-Olmos (2017).

The technological resources (mainly R\&D inputs) are another key firm-level input factor. The majority of studies find on-park firms to be more R\&D-intensive than off-park firms (Lamperti et al., 2017; Leyden et al., 2008; Monck et al., 1988; Yang et al., 2009). However, it remains largely unclear whether SP residence strengthens tenants' R\&D intensity, or whether this higher R\&D intensity can be attributed to the type of firm that is attracted to SPs (e.g. through entry criteria). Firms with limited in-house R\&D capability can gain relatively better innovative performance from being located in SPs compared to those with more inhouse R\&D capability. In any case, a minimal level of internal R\&D capability seems to be required in order to benefit from SPs (Vasquez-Urriago et al., 2015).

A firm's age is also a critical factor when analysing the contribution of SPs to their tenants, as firms are seen to be at different stages of development and have different needs (Ferguson \& Olofsson, 2004). Specifically, several SP studies comparing on- and off-park firms have found that firms located in SPs tend to be younger and slightly smaller (Lindelöf \& Löfsten, 2002; Vasquez-Urriago et al., 2015).

As firms may differ regarding the configuration of these three attributes, we explore the relationship between the different configurations of attributes and the benefits these firms perceive as gaining from being located in SPs.

According to the literature suggests that tenants' perception of these benefits depends on their profile. Based on these assumptions, we derive our propositions:

Proposition 1: Firms with a low level of performance tend to be located in the SP because of the availability of funds.

Proposition 2: Firms with higher technological development tend to be located in the SP because of proximity to a university.

Proposition 3: Young tenant firms tend to be located in the SP because of the agglomeration effects.

\section{DATA AND METHODS}

\subsection{Data collection}

The University of Valencia Science Park (PCUV) was established in 2009 as a non-profit organization of general interest; its aim is to promote the transfer of knowledge from scientific research into commercial production, as well as to facilitate and support the genesis and development of innovative business and activities with a high scientific and technical content. By the end of 2020, almost 100 firms were located in the PCUV.

Our final survey consists of a sample of 29 tenants from PCUV, obtained after applying a selection criterion that ensured the representation of the different typologies of tenant firms (see Table 2). Raw data were drawn from a questionnaire completed by the CEOs of the firms, through personal semi-structured interviews, and measured according to a five-point Likert-type scale. Table 2 describes the main features of the firms surveyed.

\subsection{Analysis method: fsQCA}

A Qualitative Comparative Analysis (QCA) is applied to our survey. This method enables the assessment of causa- 
Table 2. Descriptive statistics of selected sample

\begin{tabular}{|c|c|c|}
\hline \multicolumn{3}{|c|}{ Descriptive statistics of the selected sample of tenants } \\
\hline & Freq. & Percent \\
\hline \multicolumn{3}{|l|}{ Patent activity } \\
\hline Yes & 6 & $20 \%$ \\
\hline No & 23 & $80 \%$ \\
\hline \multicolumn{3}{|l|}{ Links with HEI } \\
\hline Intensive & 12 & $41 \%$ \\
\hline Medium & 9 & $31 \%$ \\
\hline Low & 8 & $28 \%$ \\
\hline \multicolumn{3}{|c|}{ Participation in R\&D public projects } \\
\hline Yes (international) & 13 & $45 \%$ \\
\hline Yes (national) & 6 & $21 \%$ \\
\hline No & 10 & $34 \%$ \\
\hline \multicolumn{3}{|l|}{ Sector } \\
\hline Biotech & 13 & $45 \%$ \\
\hline ICT & 8 & $28 \%$ \\
\hline Services-Consultancy & 6 & $21 \%$ \\
\hline Materials \& Nanotech & 2 & $6 \%$ \\
\hline \multicolumn{3}{|l|}{ New products/services launched } \\
\hline Yes & 23 & $79 \%$ \\
\hline No & 6 & $21 \%$ \\
\hline \multicolumn{3}{|l|}{ Employment growth } \\
\hline$>25 \%$ & 11 & $38 \%$ \\
\hline $10-25 \%$ & 5 & $17 \%$ \\
\hline $0<-10 \%$ & 1 & $4 \%$ \\
\hline 0 & 12 & $41 \%$ \\
\hline \multicolumn{3}{|l|}{ Labour productivity } \\
\hline > $300.000 € /$ employee & 4 & $14 \%$ \\
\hline 100.000 - $300.000 € /$ employee & 12 & $41 \%$ \\
\hline 50.000 - $100.000 € /$ employee & 5 & $17 \%$ \\
\hline 0-50.000 €/employee & 8 & $28 \%$ \\
\hline \multicolumn{3}{|l|}{ Turnover growth } \\
\hline$>20 \%$ & 15 & $51 \%$ \\
\hline $0<-20 \%$ & 8 & $28 \%$ \\
\hline 0 & 6 & $21 \%$ \\
\hline \multicolumn{3}{|l|}{ Age of the firm (years) } \\
\hline$>20$ years & 3 & $11 \%$ \\
\hline $7-20$ years & 16 & $55 \%$ \\
\hline 4-6 years & 5 & $17 \%$ \\
\hline $0-3$ years & 5 & $17 \%$ \\
\hline
\end{tabular}

tion or cause-effect relationships by combining features of the case-oriented approach with those of the variable-oriented approach (Ragin, 1987). This methodology is particularly appropriate for analysing systems that can reach the same final state or output after starting from different initial conditions and following different paths (Scheneider \& Wagemann, 2012). For this reason, QCA offers detailed insight into the causal relationships among configurations or combination of features (Ragin, 2008). In our study, the aim is to establish logical connections of causal conditions between the SP's tenant attributes (technology development, firm's age and firm's performance), and the three perceived potential benefits of being located onsite (proximity to a university, seeking agglomeration effects, and the availability of funds).

We rely on a specific QCA technique, namely fuzzy-set 
qualitative comparative analysis, or fsQCA (Ragin, 2000, 2008), which transforms the measures into conditions by assigning a membership degree. In fuzzy sets, the degrees of membership vary between two qualitative states: full membership (1.0) and full non-membership (0.0). Between these values the membership ranges from more out (closer to 0.0 ) to more in (closer to 1.0). Identifying the membership criteria and providing arguments to support them are essential factors for understanding the underlying assumptions (Scheneider \& Wagemann, 2012).

Over the course of the last decade, the fsQCA method has been increasingly used in entrepreneurship and innovation-related studies (Del Sarto et al., 2020; Guadix et al., 2016; Kraus et al., 2017; Mas-Verdú et al., 2015; RoigTierno et al., 2017) due to its capacity to capture a high degree of complexity through testing theory-based conditions and contextual influences, rather than focusing on single effects of individual variables (Kraus et al., 2017; Roig-Tierno et al., 2017). The use of this method allows us to examine the influence of firm profiles - not in isolation but combined with other conditions - on the perceived benefits from being located in SPs.

In fsQCA, the number of cases should be at least four times the number of conditions (Emmenegger et al., 2013). In our research we study three conditions, so the number of selected cases should be at least 12 . We selected a sample of 29 tenants from PCUV; this ensures that variety exists in all conditions and results of the sample, by using the general rule (Medina et al., 2017) that at least a quarter of cases take either value 0 or 1 of the result (in fsQCA, this is the degree of membership (above 0.5) or non-membership (below 0.5) in the outcome set).

\subsection{Outcome and conditions: Calibration of the raw data}

The first step in fsQCA is the calibration of variables and building the data matrix. Through the calibration procedure, collected data are operationalized as membership scores within predefined sets. The transformation of measures into sets was done using the direct method described by Ragin (2008). Tables $\underline{3}$ and $\underline{4}$ describe the calibration of raw data (conditions and outcomes). Being mindful of the sensitivity of fsQCA to the specification of key parameters, we based our calibration procedures on those previous studies.

The variables of our model concerning the tenant firm's profile are used as conditions: firm's age (maturity), technological level, and performance. As results (outcomes), we consider the three components proposed by the configuration-oriented support perspective: proximity to university, availability of funds, and the amplification of firms' agglomeration effects, measured according to a five-point Likert-type scale. The set membership values for the three conditions/outputs are computed by applying the log odds method, following the calibration process suggested by Ragin (2008, p. 85-94). 
Table 3. Conditions: calibration of the raw data.

\begin{tabular}{|c|c|c|c|}
\hline \multicolumn{4}{|c|}{ Condition 1: High-Tech-Development } \\
\hline Attributes & Previous literature & Score & Description \\
\hline Patent activity & $\begin{array}{l}\text { (Albahari et al., 2017) } \\
\text { (Colombo \& Delmastro, } \\
\text { 2002) }\end{array}$ & $\begin{array}{l}\text { Yes }=1 \\
\text { No }=0\end{array}$ & Dichotomous variable indicating if the firm has patenting activity. \\
\hline Links with $\mathrm{HEI}$ & $\begin{array}{l}\text { (Díez-Vial \& Montoro- } \\
\text { Sánchez, 2016) } \\
\text { (Malairaja \& Zawdie, } \\
\text { 2008) }\end{array}$ & $\begin{array}{l}\text { Intensive }=2 \\
\text { Medium }=1 \\
\text { Low }=0\end{array}$ & Variable indicating if the firm is performing joint research or collaborating with HEls. \\
\hline $\begin{array}{l}\text { Participation in R\&D public } \\
\text { projects }\end{array}$ & $\begin{array}{l}\text { (Colombo \& Delmastro, } \\
\text { 2002) }\end{array}$ & $\begin{array}{l}\text { Yes }(\text { international } \\
\text { projects })=2 \\
\text { Yes }(\text { national projects })= \\
1 \\
\text { No }=0\end{array}$ & $\begin{array}{l}\text { Variable distinguishing if the firm is involved in public } R \& D \text { public projects (national/international } \\
\text { level or none). }\end{array}$ \\
\hline $\begin{array}{l}\text { Technological level of } \\
\text { sectors of activity }\end{array}$ & $\begin{array}{l}\text { (Vásquez-Urriago et al., } \\
\text { 2014) }\end{array}$ & $\begin{array}{l}\text { High-tech }=2 \\
\text { Medium-tech = } 1 \\
\text { Low-tech }=0\end{array}$ & Variable distinguishing if the firm belongs to a high/medium/low technology sector of activity. \\
\hline $\begin{array}{l}\text { New products/services } \\
\text { launched }\end{array}$ & $\begin{array}{l}\text { (Díez-Vial \& Montoro- } \\
\text { Sánchez, 2016) }\end{array}$ & $\begin{array}{l}\text { New products }=1 \\
\text { New services }=1 \\
\text { No }=0\end{array}$ & Variable indicating if the firm is developing new products or services. \\
\hline \multicolumn{4}{|c|}{$\begin{array}{l}\text { Set membership values are computed by applying the log odds method. We consider that a firm has high technological development when it meets at least } 3 \text { of the five requirements. Anchor definition } \\
n 1=8, n 2=4, n 3=0 \text {. For details in the calibration process see (Ragin, 2008, p. 85-94). }\end{array}$} \\
\hline \multicolumn{4}{|c|}{ Condition 2: High-Performance } \\
\hline Attributes & Previous literature & Score & Description \\
\hline Employment growth & $\begin{array}{l}\text { (Díez-Vial \& Fernández- } \\
\text { Olmos, 2017) } \\
\text { (Ferguson \& Olofsson, } \\
\text { 2004) }\end{array}$ & $\begin{array}{l}\text { Yes }(>25 \%)=3 \\
\text { Yes }(10-25 \%)=2 \\
\text { Yes }(0-10 \%)=1 \\
\text { No }=0\end{array}$ & Variable distinguishing the relative employment growth in the last 3 years. \\
\hline Labour productivity & (Lee \& Yang, 2000) & $\begin{array}{l}>300.000 € / \text { employee }= \\
3 \\
100.000-300.000 \\
€ / \text { employee }=2 \\
50.000-100.000 \\
€ / \text { employee }=1 \\
0-50.000 € / \text { employee }= \\
0\end{array}$ & Variable distinguishing the average turnover per employee in the last 3 years. \\
\hline Turnover growth & $\begin{array}{l}\text { (Lee \& Yang, 2000) } \\
\text { (Lindelöf \& Löfsten, 2002) }\end{array}$ & $\begin{array}{l}\text { Yes }(>20 \%)=2 \\
\text { Yes }(0-20 \%)=1\end{array}$ & Variable distinguishing the average turnover growth in the last 3 years. \\
\hline
\end{tabular}


$\mathrm{No}=0$

\begin{tabular}{|c|c|c|c|}
\hline \multicolumn{4}{|c|}{ Condition 3: Maturity } \\
\hline Attributes & Previous literature & Score & Description \\
\hline Firm's age & $\begin{array}{l}\text { (K. A. Chan et al., 2010) } \\
\text { (Díez-Vial \& Fernández- } \\
\text { Olmos, 2015) }\end{array}$ & $\begin{array}{l}\text { Mature ( }>20 \text { years) } \\
\text { Medium ( } 7-20 \text { years) } \\
\text { Young ( } 4-6 \text { years) } \\
\text { Newly }(0-3 \text { years) }\end{array}$ & $\begin{array}{l}\text { Continuous variable that specifies the age of the firm (number of years since the founding of a firm } \\
\text { up until the time of the interview). }\end{array}$ \\
\hline
\end{tabular}

Set membership values are computed by applying the log odds method, anchor definition: $n 1=20, n 2=8.5, n 3=3$. For details in the calibration process see (Ragin, 2008, p. 85-94). 
Table 4. Outcomes: calibration of the raw data.

\begin{tabular}{|c|c|c|c|}
\hline \multicolumn{4}{|l|}{ Outcome 1: Proximity to University } \\
\hline Attributes & Previous literature & Score & Description \\
\hline Access to talent (I): students/graduated & $\begin{array}{l}\text { (Audretsch et al., 2005) } \\
\text { (Ferguson \& Olofsson, } \\
2004 \text { ) } \\
\text { (Lindelöf \& Löfsten, } \\
\text { 2002) }\end{array}$ & $\begin{array}{l}5 \text { points Likert scale: } \\
\text { Strongly disagree }=1 \\
\text { Neither agree nor } \\
\text { disagree }=3 \\
\text { Strongly agree }=5\end{array}$ & $\begin{array}{l}\text { Location in the SP because of the possibilities of accessing the University's human } \\
\text { capital (students/graduates). }\end{array}$ \\
\hline Access to talent (II): researchers & $\begin{array}{l}\text { (K. F. Chan \& Lau, 2005) } \\
\text { (Koh et al., 2005) } \\
\text { (Audretsch et al., 2005) } \\
\text { (Ferguson \& Olofsson, } \\
\text { 2004) }\end{array}$ & $\begin{array}{l}5 \text { points Likert scale: } \\
\text { Strongly disagree = } 1 \\
\text { Neither agree nor } \\
\text { disagree }=3 \\
\text { Strongly agree = } 5\end{array}$ & $\begin{array}{l}\text { Location in the SP because of the possibilities of accessing the University human } \\
\text { capital (researchers). }\end{array}$ \\
\hline Access to the University science facilities/equipment & $\begin{array}{l}\text { (K. F. Chan \& Lau, 2005) } \\
\text { (Koh et al., 2005) }\end{array}$ & $\begin{array}{l}5 \text { points Likert scale: } \\
\text { Strongly disagree }=1 \\
\text { Neither agree nor } \\
\text { disagree }=3 \\
\text { Strongly agree }=5\end{array}$ & $\begin{array}{l}\text { Location in the SP because of the possibilities of accessing the University science } \\
\text { facilities/equipment. }\end{array}$ \\
\hline
\end{tabular}

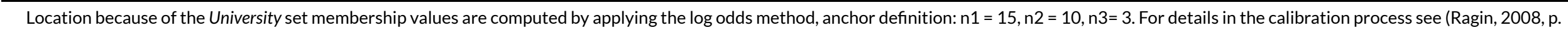
85-94).

\begin{tabular}{|c|c|c|c|}
\hline \multicolumn{4}{|l|}{ Outcome 2: Agglomeration effects } \\
\hline Attributes & Previous literature & Score & Description \\
\hline Tenant facilities in SP & $\begin{array}{l}\text { (McAdam \& McAdam, } \\
\text { 2008) } \\
\text { (Dettwiler et al., 2006) } \\
\text { (Kihlgren, 2003) } \\
\text { (Bakouros et al., 2002) }\end{array}$ & $\begin{array}{l}5 \text { points Likert scale: } \\
\text { Strongly disagree }=1 \\
\text { Neither agree nor } \\
\text { disagree }=3 \\
\text { Strongly agree }=5\end{array}$ & Location in the SP because of the facilities offered by the SP for the tenants. \\
\hline $\begin{array}{l}\text { Access to shared facilities in the SP (meeting rooms and } \\
\text { common reception) }\end{array}$ & $\begin{array}{l}\text { (McAdam \& McAdam, } \\
\text { 2008) } \\
\text { (Dettwiler et al., 2006) } \\
\text { (Kihlgren, 2003) } \\
\text { (Bakouros et al., 2002) }\end{array}$ & $\begin{array}{l}5 \text { points Likert scale: } \\
\text { Strongly disagree }=1 \\
\text { Neither agree nor } \\
\text { disagree }=3 \\
\text { Strongly agree }=5\end{array}$ & Location in the SP because of the possibility of accessing the shared facilities. \\
\hline Prestige and well-established image & $\begin{array}{l}\text { (Radosevic \& } \\
\text { Myrzakhmet, 2009) } \\
\text { (McAdam \& McAdam, } \\
\text { 2008) } \\
\text { (Ferguson \& Olofsson, } \\
\text { 2004) } \\
\text { (Bakouros et al., 2002) }\end{array}$ & $\begin{array}{l}5 \text { points Likert scale: } \\
\text { Strongly disagree = } 1 \\
\text { Neither agree nor } \\
\text { disagree = } 3 \\
\text { Strongly agree = } 5\end{array}$ & $\begin{array}{l}\text { Location in the SP because of prestige and well-established image of being located } \\
\text { in the SP. }\end{array}$ \\
\hline
\end{tabular}


Network opportunities and social capital

(Yang et al., 2009)

(Dettwiler et al., 2006)

Bakouroset

inos et al., 2002)

(Lindelöf \& Löfsten

2002)

5 points Likert scale:

Strongly disagree $=1$

Neither agree nor

disagree $=3$

Strongly agree $=5$
Location in the SP because of the access to network opportunities and social capital.

Location because of the agglomeration effects set membership values are computed by applying the log odds method, anchor definition: $n 1=20, n 2=15$, $n 3=4$. For details in the calibration process see (Ragin 2008, p. 85-94)

\begin{tabular}{|c|c|c|c|}
\hline \multicolumn{4}{|l|}{ Outcome 3: Availability of funds } \\
\hline Attributes & Previous literature & Score & Description \\
\hline Access to public funds & $\begin{array}{l}\text { (Radosevic \& } \\
\text { Myrzakhmet, 2009) } \\
\text { (Kihlgren, 2003) }\end{array}$ & $\begin{array}{l}5 \text { points Likert scale: } \\
\text { Strongly disagree }=1 \\
\text { Neither agree nor } \\
\text { disagree }=3 \\
\text { Strongly agree }=5\end{array}$ & Location in the SP because of the possibilities of accessing public funds. \\
\hline Access to venture capitalists & $\begin{array}{l}\text { (Radosevic \& } \\
\text { Myrzakhmet, 2009) } \\
\text { (McAdam \& McAdam, } \\
\text { 2008) } \\
\text { (Kihlgren, 2003) }\end{array}$ & $\begin{array}{l}5 \text { points Likert scale: } \\
\text { Strongly disagree }=1 \\
\text { Neither agree nor } \\
\text { disagree }=3 \\
\text { Strongly agree }=5\end{array}$ & Location in the SP because of the possibilities of accessing private investors. \\
\hline Rental subsidies & $\begin{array}{l}\text { (Radosevic \& } \\
\text { Myrzakhmet, 2009) } \\
\text { (K. F. Chan \& Lau, 2005) } \\
\text { (Kihlgren, 2003) }\end{array}$ & $\begin{array}{l}5 \text { points Likert scale: } \\
\text { Strongly disagree }=1 \\
\text { Neither agree nor } \\
\text { disagree }=3 \\
\text { Strongly agree }=5\end{array}$ & Location in the SP because of the rental subsidies. \\
\hline
\end{tabular}

Location because of the availability of funds set membership values are computed by applying the log odds method, anchor definition: $\mathrm{n} 1=15$, n2 = 10, $\mathrm{n} 3=3$. For details in the calibration process see (Ragin, 2008, p. 85-94) 
Table 5. Truth table derived from fuzzy-set data.

\begin{tabular}{llll|l|lll}
\hline & \multicolumn{1}{c}{ Conditions } & \multicolumn{5}{c}{ Outcomes } \\
\cline { 2 - 7 } Rows & $\begin{array}{l}\text { High-Tech- } \\
\text { Development }\end{array}$ & $\begin{array}{l}\text { High- } \\
\text { performance }\end{array}$ & Maturity & $\begin{array}{l}\text { Number } \\
\text { of cases }\end{array}$ & $\begin{array}{l}\text { Proximity } \\
\text { to } \\
\text { University }\end{array}$ & $\begin{array}{l}\text { Agglomeration } \\
\text { effects }\end{array}$ & $\begin{array}{l}\text { Availability } \\
\text { of funds }\end{array}$ \\
\hline 1 & 1 & 0 & 0 & 4 & 1 & 1 & 1 \\
2 & 1 & 1 & 1 & 11 & 1 & 0 & 0 \\
3 & 0 & 0 & 1 & 2 & 0 & 1 & 1 \\
4 & 0 & 0 & 0 & 8 & 0 & 1 & 0 \\
\hline
\end{tabular}

Note: Rows are labelled as follows: 1 membership in the set, 0 non-membership in the set $2^{3} .4$ possible configurations are not displayed in the truth table as they contain less than 2 cases and we do not consider them as empirical evidence.

\subsection{Truth table and logical minimization}

Once the calibration process is complete, all the logically possible combinations of causal conditions are first listed in a data matrix called a "truth table", which includes the empirical outcome associated with each configuration.

The second step reduces the number of rows in the table by considering two aspects: a frequency threshold and a consistency threshold. When the total $\mathrm{N}$ (number of cases) is relatively small, the frequency threshold should be 1 or 2. In our study, we apply a consistency threshold of 0.85 , which is superior to 0.8 (Ragin, 2008), and a frequency threshold of 2 . Table 5 shows the truth table obtained. Our configurations capture $86 \%$ of the cases (25 out of 29), above the minimum recommendation of $75-80 \%$ of the cases (Ragin et al., 2017, p. 53).

The third step simplifies the truth table through an algorithm based on Boolean algebra. In our study, we apply the Quine-McCluskey algorithm to simplify the complexity and arrive at a more parsimonious answer. Depending on the simplifying approach used, the truth table analysis yields three different solution terms: (1) complex, (2) parsimonious, and (3) intermediate (Ragin, 2008, p. 148-150). The intermediate solution has been selected as being the most suitable for theoretical interpretation, according to (Fiss, 2011).

\section{RESULTS}

The fsQCA method recommends starting by checking the presence of necessary conditions to determine whether any causal condition can be considered as a necessary condition for the outcome. To accept a condition as necessary, the threshold for consistency should be high (> .9) and the coverage should not be too low (> .5) (Ragin, 2006).

Table 6 shows the results of the analysis of necessary conditions, considering both the presence or the absence $(\sim)$ of the condition. The consistency level falls below the threshold of 0.9 in all cases, except for one condition connected to the absence of "High-Performance" ( High-Performance) and the output "Availability of funds". Consequently, our analysis reveals that the only necessary condition for being located in a science park to seek more fluent "Availability of funds" (access to funding) is a firm's relatively low economic performance.
Once the necessary conditions have been fulfilled, the fsQCA suggests undertaking an analysis of sufficient conditions in order to identify all the conditions (X) that are sufficient for the outcome $(\mathrm{Y})$ to occur. This analysis is based on the idea that if one or more combined conditions exhibit the same result, then these conditions form a subset within the (super) set of the outcome. For this study, we consider a frequency threshold of 2.0 and a consistency threshold of 0.85 .

Table 7 reports the configurations of conditions that are sufficient for a firm to locate to a science park, connected with each of the three perceived benefits of SPs. We found six configurations with a consistency greater than 0.85 , indicating that they are sufficient for the outcome to occur. Solution coverage and solution consistency comply with criteria given by (Ragin, 2008) and (Woodside, 2013), according to whom consistency must be greater than 0.75 and coverage must be greater than 0.25 .

\section{DISCUSSION}

Our findings reveal the extent to which certain key attributes of the tenant firms, labelled as firm-level input factors, influence their perception of benefits related to the SP business support services, from a configurational-oriented perspective. Previous studies that examined the tenant's perceived benefits of the SP location (Dettwiler et al., 2006; Westhead \& Batstone, 1998, 1999) have treated the on-park firms as a homogeneous category. However, the diversity of firms located in SPs is significant; thus, it is necessary to examine the different perceptions towards the benefits of being located in SPs (Vasquez-Urriago et al., 2015).

Our findings, obtained through application of the fsQCA method, are summarized in Table 8.

Our Proposition 1 postulated that the firms with a lower level of performance opted to be located in SPs in order to find more funding opportunities. A major finding highlights that the absence of high performance in a firm is a necessary condition for being located in a science park when the main perceived benefit is the availability of funds. This result means that the possibility of accessing financing (private/public investment and low rental cost) is the main appealing factor in SPs for tenants that lack a high level of performance. A similar result was found in previous studies (Kihlgren, 2003; Radosevic \& Myrzakhmet, 2009), but these 
Table 6. Analysis of necessary conditions

\begin{tabular}{|c|c|c|}
\hline Outcome: Proximity to University & Consistency & Coverage \\
\hline High-Tech-Development & 0.77 & 0.90 \\
\hline$\sim$ High-Tech-Development & 0.39 & 0.64 \\
\hline High-Performance & 0.60 & 0.86 \\
\hline$\sim$ High-Performance & 0.58 & 0.76 \\
\hline Maturity & 0.61 & 0.81 \\
\hline$\sim$ Maturity & 0.54 & 0.76 \\
\hline Outcome: Agglomeration effects & Consistency & Coverage \\
\hline High-Tech-Development & 0.60 & 0.76 \\
\hline$\sim$ High-Tech-Development & 0.53 & 0.92 \\
\hline High-Performance & 0.55 & 0.84 \\
\hline$\sim$ High-Performance & 0.66 & 0.93 \\
\hline Maturity & 0.57 & 0.80 \\
\hline$\sim$ Maturity & 0.61 & 0.92 \\
\hline Outcome: Availability of funds & Consistency & Coverage \\
\hline High-Tech-Development & 0.66 & 0.47 \\
\hline High-Tech-Development & 0.68 & 0.67 \\
\hline High-Performance & 0.56 & 0.48 \\
\hline$\sim$ High-Performance & 0.91 & 0.72 \\
\hline Maturity & 0.56 & 0.45 \\
\hline$\sim$ Maturity & 0.79 & 0.67 \\
\hline
\end{tabular}

Table 7. Analysis of sufficient conditions

\begin{tabular}{|c|c|c|c|}
\hline Outcome: Proximity to University & Raw coverage & Unique Coverage & Consistency \\
\hline (1) High-Tech-Development ${ }^{*} \sim$ High-Performance* $\sim$ Maturity & 0.34 & 0.18 & 0.98 \\
\hline (2) High-Tech-Development * High-Performance* Maturity & 0.48 & 0.32 & 0.92 \\
\hline \multicolumn{4}{|l|}{ Solution coverage: 0.66} \\
\hline \multicolumn{4}{|l|}{ Solution consistency: 0.94} \\
\hline Outcome: Agglomeration effects & Raw coverage & Unique Coverage & Consistency \\
\hline (3) $\sim$ High-Performance ${ }^{*} \sim$ Maturity & 0.51 & 0.14 & 0.96 \\
\hline (4) High-Tech-Development * High-Performance & 0.48 & 0.10 & 0.97 \\
\hline \multicolumn{4}{|l|}{ Solution coverage: 0.62} \\
\hline \multicolumn{4}{|l|}{ Solution consistency: 0.94} \\
\hline Outcome: Availability of funds & Raw coverage & Unique Coverage & Consistency \\
\hline (5) High-Tech-Development ${ }^{*} \sim$ High-Performance ${ }^{*} \sim$ Maturity & 0.51 & 0.31 & 0.89 \\
\hline (6) High-Tech-Development * High-Performance * Maturity & 0.39 & 0.19 & 0.90 \\
\hline \multicolumn{4}{|l|}{ Solution coverage: 0.70} \\
\hline Solution consistency: 0.88 & & & \\
\hline
\end{tabular}

referred to emerging economies with limited capital markets, and which experienced difficulties in transforming resources and knowledge into marketable outputs. This finding reveals that tenant firms with lower performance indicators view SPs as organizations that can compensate for missing markets, interactions and skills, as well as provide access to lower rents and enhance opportunities to obtain funding. Hence, Proposition 1 is largely met.

Our analysis of sufficient conditions leads to two signif- icant combinations of attributes. Configurations (5) and (6) show that the absence of high performance in high-techdevelopment non-mature firms, and the absence of high performance in non-high-tech developed mature firms, are sufficient conditions for being located in SPs when the critical perceived benefit is the availability of funds. Configuration (5) resembles the profile of firms identified by $(\mathrm{Ng}$ et al., 2019) as young technology-based firms, which usually face major difficulties in obtaining finance. Configuration 
Table 8. Tenant's characteristics and perceived benefits of being located in a science park

\begin{tabular}{|c|c|c|c|c|c|c|}
\hline \multirow{2}{*}{$\begin{array}{l}\text { Tenant's } \\
\text { characteristics }\end{array}$} & \multicolumn{2}{|c|}{ Proximity to University } & \multicolumn{2}{|c|}{ Agglomeration effects } & \multicolumn{2}{|c|}{ Availability of funds } \\
\hline & $\begin{array}{l}\text { Configuration } \\
\text { (1) }\end{array}$ & $\begin{array}{l}\text { Configuration } \\
\text { (2) }\end{array}$ & $\begin{array}{l}\text { Configuration } \\
\text { (3) }\end{array}$ & $\begin{array}{l}\text { Configuration } \\
\text { (4) }\end{array}$ & $\begin{array}{l}\text { Configuration } \\
\text { (5) }\end{array}$ & $\begin{array}{l}\text { Configuration } \\
\text { (6) }\end{array}$ \\
\hline $\begin{array}{l}\text { High-Tech- } \\
\text { Development }\end{array}$ & $x$ & $x$ & & & $x$ & \\
\hline $\begin{array}{l}\sim \text { High-Tech- } \\
\text { Development }\end{array}$ & & & & $x$ & & $x$ \\
\hline $\begin{array}{l}\text { High- } \\
\text { Performance }\end{array}$ & & $x$ & & & & \\
\hline $\begin{array}{l}\text { High- } \\
\text { Performance }\end{array}$ & $x$ & & $x$ & $x$ & $X$ & $x$ \\
\hline Maturity & & $x$ & & & & $x$ \\
\hline Maturity & $x$ & & $x$ & & $x$ & \\
\hline
\end{tabular}

(6) fits with the tenant profile identified by (Radosevic \& Myrzakhmet, 2009), who tend to view the SP as a solution to counteract some "missing prerequisites". These non-hightech mature firms with lower performance seek to be located in SPs because of the possibility of accessing finance opportunities, lower rental costs, and benefitting from the SP's image.

Our Proposition 2 postulated that technology-driven firms who were located in SPs placed the highest value on proximity to a university. Our analysis highlights that the presence of a high-tech development alone is not a necessary condition for being located in SPs when the main perceived benefit is the proximity to a university.

From our analyses of sufficient conditions, we found two meaningful configurations relating to the outcome "proximity to university". Configuration 1 reveals that for the proximity to university to be perceived as a significant benefit of being located in the SP, the sufficient condition is for the firm to meet the following pattern: younger, high-tech and low-performing. Configuration 2 proposes another alternative profile giving the same outcome: high-tech, highperforming mature firms. Both configurations are consistent with previous literature, as they represent similar tenant profiles to those identified by (Ng et al., 2019) as young technology-based firms (Configuration 1) and mature science-based firms (Configuration 2). Both spin-offs and mature firms (multinationals) tend to set up long-term agreements with universities as a result of their higher capacity to acquire and assimilate the institutions' knowledge (Díez-Vial \& Montoro-Sánchez, 2016). Their decision to locate close to universities presumably aligns with their hopes of taking advantage of knowledge spill-overs (Audretsch et al., 2005). Thus, Proposition 2 is also largely fulfilled.

Proposition 3 postulated that younger tenants were more attracted by the agglomeration effects favoured by being located in SPs. With no necessary conditions found, our analysis of sufficient conditions leads to two solutions. Configuration 3, gathering younger firms with lower performance, and Configuration 4, grouping non-technology low-performing firms, are both sufficient conditions to be located in SPs, being attracted by the perceived benefit of agglomeration effects. Both configurations are consistent with previous literature, as a firm's performance, on average, is improved by the agglomeration effects (Audretsch \& Feldman, 1996; Beaudry \& Swann, 2009; McCann \& Folta, 2011). According to Configuration 3, low-performing firms expect to upgrade their performance indicators through the clustering effects provided by the SP environment. Configuration 4 suggests that firms with a lower technological level are more inclined to perceive in the SP the advantages of physical infrastructures, status and prestige. Conversely, high-tech firms are more eager to collaborate with universities and trigger technology transfer flows with other firms. Consequently, in line with (McCann \& Folta, 2011), our study confirms Proposition 3, that younger firms will benefit more from agglomeration effects.

\section{CONCLUSIONS}

Following the recent literature on the contribution of SPs to the creation of value for tenants, and the perception of the benefits of the attributes of the SP among science park tenants (Albahari et al., 2019; Ng et al., 2019), we perform a fsQCA analysis(Ragin, 1987). The fsQCa method is a configurational comparative methodology that is growing in popularity (Kraus et al., 2017; Roig-Tierno et al., 2017).

The results of the fuzzy-set analysis confirm that the tenant firms hold divergent perceptions of the benefits offered by being located in SPs. The purpose of the fsQCA method is not to demonstrate the existence and the magnitude of a causal relationship between two variables, but rather to reveal patterns that support the existence of such a causal relationship. The findings obtained confirm our propositions and are consistent with the literature on value creation for SP tenants (Albahari et al., 2019; Ferguson \& Olofsson, 2004; Lindelöf \& Löfsten, 2002; Ng et al., 2019). This study discloses the priority that each tenant category ascribes to the main benefits of being located in the SP. In addition, our analysis has determined the profiles of tenant firms that are more attracted by each of the three typical benefits provided by the SP; it has also allowed us to determine in what sense the perception of each attribute differs depending on the tenant profile.

From an academic perspective, this study offers additional insights into the further conceptualization of SP de- 
velopment; it also fills the research gap identified by $\mathrm{Al}-$ bahari et al. (2019) regarding how these initiatives create value for their tenants. SP tenant firms represent a heterogeneous group, and the SP impact is not uniform across all firms. Therefore, our main contribution at the theoretical level lies in linking specific types of tenants with perceived benefits attached to the SP facilities and services; this provides insight into the difference in preferences between firms.

In terms of managerial implications, our results provide valuable indications for firms and entrepreneurs considering the benefits of setting up in a science park. For practitioners, our findings allow for better-informed decisionmaking in the design and management of SPs. As remarked by $\mathrm{Ng}$ et al. (2019), the development of a science park involves substantial investments, which makes understanding the expectations and preferences of their future tenant firms essential. Our results will help existing and projected SPs by identifying those attributes most appreciated by different typologies of current and future tenants. In addition, our findings are also helpful for institutions and agents who seek to evaluate the impact and prospects of SPs as publicled development initiatives that are oriented towards fostering innovation and technology transfer.

Although the fsQCA technique overcomes problems related to sample size, and it is less restrictive than conventional statistical methods (Ragin, 1987), our study is, how- ever, not free from limitations. First, our results offer a limited view of the perception of park tenants, as our sample included only tenants from the University of Valencia Science Park. Despite offering useful insights into the tenants' opinions of a science park, further research with a broader sample is needed in order to generalize these findings to the entire community of SPs in Spain. A larger and more randomly selected sample is required to explore differences across countries and yield more precise and rigorous results.

A second limitation stems from our decision to focus our research on the configuration-oriented support component (Albahari et al., 2019). Future studies could examine perceived benefits derived from a process-oriented support component, which is related to the services and activities offered to tenants, such as incubation, training and networking activities. Thirdly, other causal conditions, besides a firm's age, technological development and performance, could be considered in future research. Finally, at the methodological level, a more comprehensive econometric framework would allow measurement of the strengths as well as weighting of the benefits.

Submitted: July 19, 2021 CST, Accepted: January 21, 2022 CST 


\section{REFERENCES}

Albahari, A. a, Pérez-Canto, S., \& Landoni, P. (2010). Munich Personal RePEc Archive Science and Technology Parks impacts on tenant organisations : a review of literature. MPRA Paper, 41914.

Albahari, A., Klofsten, M., \& Rubio-Romero, J. C. (2019). Science and Technology Parks: a study of value creation for park tenants. Journal of Technology Transfer, 44(4), 1256-1272. https://doi.org/10.1007/s1 0961-018-9661-9

Albahari, A., Pérez-Canto, S., Barge-Gil, A., \& Modrego, A. (2017). Technology Parks versus Science Parks: Does the university make the difference? Technological Forecasting and Social Change, 116, 13-28. https://doi.org/10.1016/j.techfore.2016.11.012

Amoroso, SaraLink, A., \& Wright, M. (Eds.). (2019). Science and Technology Parks and Regonal Economic Development. Palgrave Macmillan. https://doi.org/1 0.1007/978-3-030-30963-3

Audretsch, D. B., \& Feldman, M. P. (1996). R\&D Spillovers and the Geography of Innovation and Production. American Economic Review, 86(3), 630-640. https://doi.org/10.2307/2118216

Audretsch, D. B., Lehmann, E. E., \& Warning, S. (2005). University spillovers and new firm location $₫$. Research Policy, 34, 1113-1122. https://doi.org/10.101 6/j.respol.2005.05.009

Autio, E., \& Klofsten, M. (1998). A comparative study of two European business incubators. Journal of Small Business Management, 36(1), 30-43.

Bakouros, Y. L., Mardas, D. C., \& Varsakelis, N. C. (2002). Science park, a high tech fantasy?: An analysis of the science parks of Greece. Technovation, 22(2), 123-128. https://doi.org/10.1016/S0166-4972(00)000 $\underline{87-0}$

Beaudry, C., \& Swann, G. M. P. (2009). Firm growth in industrial clusters of the United Kingdom. Small Business Economics, 32(4), 409-424. https://doi.org/1 $\underline{0.1007 / \mathrm{s} 11187-007-9083-9}$

Chan, K. A., Oerlemans, L. A. G., \& Pretorius, M. W. (2010). Knowledge exchange behaviors of science park firms: The Innovation Hub case. Technology Analysis and Strategic Management, February. http s://doi.org/10.1080/09537320903498546

Chan, K. F., \& Lau, T. (2005). Assessing technology incubator programs in the science park: The good, the bad and the ugly. Technovation, 25(10), 1215-1228. ht tps://doi.org/10.1016/j.technovation.2004.03.010

Colombo, M. G., \& Delmastro, M. (2002). How effective are technology incubators? Evidence from Italy. Research Policy, 31, 1103-1122. https://doi.org/10.110 8/S1574-0765(2010)0000014007

Del Sarto, N., Isabelle, D. A., \& Di Minin, A. (2020). The role of accelerators in firm survival: An fsQCA analysis of Italian startups. Technovation, 90-91(September 2018), 102102. https://doi.org/10.1 016/i.technovation.2019.102102
Dettwiler, P., Lindelöf, P., \& Löfsten, H. (2006). Utility of location: A comparative survey between small new technology-based firms located on and off Science Parks - Implications for facilities management. Technovation, 26(4), 506-517. https://doi.org/10.1016/ j.technovation.2005.05.008

Díez-Vial, I., \& Fernández-Olmos, M. (2015). Knowledge spillovers in science and technology parks: how can firms benefit most? Journal of Technology Transfer, 40(1), 70-84. https://doi.org/10.1 007/s10961-013-9329-4

Díez-Vial, I., \& Fernández-Olmos, M. (2017). The effect of science and technology parks on firms' performance: how can firms benefit most under economic downturns? Technology Analysis and Strategic Management, 29(10), 1153-1166. https://do i.org/10.1080/09537325.2016.1274390

Díez-Vial, I., \& Montoro-Sánchez, Á. (2016). How knowledge links with universities may foster innovation: The case of a science park. Technovation, 50-51, 41-52. https://doi.org/10.1016/j.technovatio $\underline{\text { n.2015.09.001 }}$

Emmenegger, P., Kvist, J., \& Skaaning, S.-E. (2013). Applications in Comparative Welfare-State Research Making the Comparativ of QCA. Political Research Quarterly, 66(1), 185-190. https://doi.org/10.1177/10 $65912912468269 d$

Felsenstein, D., \& Felsenstein, D. (1994). UniversityRelated Science Parks - " Seedbeds " or " Enclaves " of Innovation? University-related science parks - ' seedbeds ' or ' enclaves' of innovation? Technovation, 4972(MARCH 1994), 93-110. https://doi.org/10.1016/ 0166-4972(94)90099-X

Ferguson, R., \& Olofsson, C. (2004). Science Parks and the Development of NTBFs - Location, Survival and Growth. Journal of Technology Transfer, 5-17.

Ferrara, M., Lamperti, F., \& Mavilia, R. (2014). The Impact of Technopoles and Science Parks on the Regional and Local Innovation Systems. In Design a Pattern of Sustainable Growth. Innovation, Education, Energy and Environment (Issue September). https://do i.org/10.14505/despag.2014.ch3

Fiss, P. C. (2011). Building better causal theories: A fuzzy set approach to typologies in organization research. Academy of Management Journal, 54(2), 393-420. https://doi.org/10.5465/AMJ.2011.60263120

Fukugawa, N. (2006). Science parks in Japan and their value-added contributions to new technology-based firms. International Journal of Industrial Organization, 24(2), 381-400. https://doi.org/10.1016/j.ijindorg.200 $\underline{5.07 .005}$

Guadix, J., Carrillo-Castrillo, J., Onieva, L., \& Navascués, J. (2016). Success variables in science and technology parks. Journal of Business Research, 69(11), 4870-4875. https://doi.org/10.1016/i.jbusres.2016.0 $\underline{4.045}$ 
Guo, Y., \& Verdini, G. (2015). The role of geographical proximity in the establishment and development of science parks -evidence from Nanjing, China. Asian Geographer, 32(2), 117-133. https://doi.org/10.1080/1 0225706.2015.1079726

Gwebu, K. L., Sohl, J., \& Wang, J. (2019). Differential performance of science park firms: an integrative model. Small Business Economics, 52(1), 193-211. http s://doi.org/10.1007/s11187-018-0025-5

Hansson, F., Husted, K., \& Vestergaard, J. (2005). Second generation science parks: From structural holes jockeys to social capital catalysts of the knowledge society. Technovation, 25(9), 1039-1049. $\underline{\mathrm{h}}$ ttps://doi.org/10.1016/j.technovation.2004.03.003

Kihlgren, A. (2003). Promotion of innovation activity in Russia through the creation of science parks: The case of St. Petersburg (1992-1998). Technovation, 23(1), 65-76. https://doi.org/10.1016/S0166-4972(0 1) $00077-3$

Koh, F. C. C., Koh, W. T. H., \& Tschang, F. T. (2005). An analytical framework for science parks and technology districts with an application to Singapore. Journal of Business Venturing, 20(2), 217-239. http s://doi.org/10.1016/j.jbusvent.2003.12.002

Kraus, S., Ribeiro-soriano, D., \& Schüssler, M. (2017). Fuzzy-set qualitative comparative analysis ( fsQCA ) in entrepreneurship and innovation research - The rise of a method in entrepreneurship and innovation research -. International Entrepreneurship and Management Journal ·, July. https://doi.org/10.1007/s1 1365-017-0461-8

Lamperti, F., Mavilia, R., \& Castellini, S. (2017). The role of Science Parks: a puzzle of growth, innovation and R\&D investments. Journal of Technology Transfer, 42(1), 158-183. https://doi.org/10.1007/s10961-015-9 455-2

Lecluyse, L., \& Knockaert, M. (2020). Disentangling satisfaction of tenants on science parks: A multiple case study in Belgium. Technovation, 98(August), 102156. https://doi.org/10.1016/j.technovation.202 $\underline{0.102156}$

Lecluyse, L., Knockaert, M., \& Spithoven, A. (2018). The contribution of science parks: a literature review and future research agenda. In Journal of Technology Transfer (Vol. 44, Issue 2). Springer US. https://doi.or g/10.1007/s10961-018-09712-X

Lee, W. H., \& Yang, W. T. (2000). Cradle of Taiwan high technology industry development - Hsinchu Science Park (HSP). Technovation, 20(1), 55-59. https://doi.or g/10.1016/S0166-4972(99)00085-1

Leyden, D. P., Link, A. N., \& Siegel, D. S. (2008). A Theoretical and Empirical Analysis of the Decision to Locate on a University Research Park. IEEE TRANSACTIONS ON ENGINEERING MANAGEMENT, 55(1), 23-28.

Lindelöf, P., \& Löfsten, H. (2002). Growth, management and financing of new technology-based firmsassessing value-added contributions of firms located on and off Science Parks. Omega, 30(3), 143-154. http s://doi.org/10.1016/S0305-0483(02)00023-3
Löfsten, H., \& Lindelöf, P. (2003). Determinants for an entrepreneurial milieu: Science Parks and business policy in growing firms. Technovation, 23(1), 51-64. ht tps://doi.org/10.1016/S0166-4972(01)00086-4

Löfsten, H., \& Lindelöf, P. (2005). R\&D networks and product innovation patterns - Academic and nonacademic new technology-based firms on Science Parks. Technovation, 25(9), 1025-1037. https://doi.or g/10.1016/j.technovation.2004.02.007

Malairaja, C., \& Zawdie, G. (2008). Science parks and university-industry collaboration in Malaysia. Technology Analysis and Strategic Management, 20(6), 727-739. https://doi.org/10.1080/0953732080242643 $\underline{2}$

Mas-Verdú, F., Ribeiro-Soriano, D., \& Roig-Tierno, N. (2015). Firm survival: The role of incubators and business characteristics. Journal of Business Research, 68(4), 793-796. https://doi.org/10.1016/i.jbusres.201 $\underline{4.11 .030}$

McAdam, M., \& McAdam, R. (2008). High tech start-ups in University Science Park incubators: The relationship between the start-up's lifecycle progression and use of the incubator's resources. Technovation, 28(5), 277-290. https://doi.org/10.1016/ j.technovation.2007.07.012

McCann, B. T., \& Folta, T. B. (2011). Performance differentials within geographic clusters. Journal of Business Venturing, 26(1), 104-123. https://doi.org/1 0.1016/j.jbusvent.2009.04.004

Medina, I., Castillo Ortiz, P. J., \& Álamos-Concha, Priscila Rihoux, B. (2017). Análisis cualitativo comparado (QCA). Madrid, Centro de Investigaciones Sociológicas.

Mian, S., Lamine, W., \& Fayolle, A. (2016). Technology Business Incubation: An overview of the state of knowledge. Technovation, 50-51, 1-12. https://doi.or g/10.1016/i.technovation.2016.02.005

Monck, C. S. P., Porter, R. B., Quintas, P. R., \& Storey, D. J. (1988). Science Parks and the Growth of High Technology Firms. In Bulletin of Science, Technology \& Society (Vol. 10). Bulletin of Science, Technology \& Society. https://doi.org/10.1177/027046769001000430

Ng, W. K. B., Appel-Meulenbroek, R., Cloodt, M., \& Arentze, T. (2017). Real Estate Resourcing on Science Parks : Exploratory Overview of European Science Parks. Proceedings of the 14th International Conference on Intellectual Capital, Knowledge Management \& Organisational Learning, 2017.

Ng, W. K. B., Appel-Meulenbroek, R., Cloodt, M., \& Arentze, T. (2020). Perceptual measures of science parks: Tenant firms' associations between science park attributes and benefits. Technological Forecasting and Social Change, October, 120408. https://doi.org/1 $\underline{0.1016 / j . t e c h f o r e .2020 .120408}$

Ng, W. K. B., Junker, R., Appel-Meulenbroek, R., Cloodt, M., \& Arentze, T. (2019). Perceived benefits of science park attributes among park tenants in the Netherlands. Journal of Technology Transfer, 45(4), 1196-1227. https://doi.org/10.1007/s10961-019-0974 $\underline{4-\mathrm{X}}$ 
Phan, P. H., Siegel, D. S., \& Wright, M. (2005). Science parks and incubators: Observations, synthesis and future research. Journal of Business Venturing, 20(2), 165-182. https://doi.org/10.1016/j.jbusvent.2003.12.0 $\underline{01}$

Radosevic, S., \& Myrzakhmet, M. (2009). Between vision and reality: Promoting innovation through technoparks in an emerging economy. Technovation, 29(10), 645-656. https://doi.org/10.1016/j.technovati on.2009.04.001

Ragin, C. C. (1987). The comparative method: moving beyond qualitative and quantitative strategies. University of California Press, Berkeley.

Ragin, C. C. (2000). Fuzzy-Set Social Science. In University of Chicago Press. https://doi.org/10.1017/s0 $\underline{022381607080309}$

Ragin, C. C. (2006). Set relations in social research: Evaluating their consistency and coverage. Political Analysis, 14(3), 291-310. https://doi.org/10.1093/pan/ $\underline{\text { mpj019 }}$

Ragin, C. C. (2008). Redesigning Social Inquiry: Fuzzy Sets and Beyond. In University of Chicago Press.

Ragin, C. C., Patros, T., Strand, S. I., \& Rubinson, C. (2017). USER' S GUIDE TO Fuzzy-Set / Qualitative Comparative Analysis. July, 62.

Roig-Tierno, N., Gonzalez-Cruz, T. F., \& LlopisMartinez, J. (2017). An overview of qualitative comparative analysis: A bibliometric analysis. Journal of Innovation and Knowledge, 2(1), 15-23. https://doi.o rg/10.1016/j.jik.2016.12.002

Salvador, E. (2011). Are science parks and incubators good "brand names" for spin-offs? The case study of Turin. Journal of Technology Transfer, 36(2), 203-232. https://doi.org/10.1007/s10961-010-9152-0

Scheneider, C. Q., \& Wagemann, C. (2012). Set Theoretic Methods for the Social Sciences. A guide to Qualitative Comparative Analysis. In CAMBRIDGE.

Storey, D. J., \& Tether, B. (1996). New Technology-Based Firms (NTBFs) in Europe, an European Innovation Monitoring System study for The Innovation Programme, EIMS Publication No. 31, Directorate General XIII European Comission.

Storey, D. J., \& Tether, B. (1998). New technology-based firms in the European union: an introduction. Research Policy, 26(933-946).

Van Dierdonck, R., Debackere, K., \& Rappa, M. A. (1991). An assessment of science parks: Towards a better understanding of their role in the diffusion of technological knowledge. R\&D Management, 21(2), 109-124. https://doi.org/10.1111/j.1467-9310.1991.tb 00741.x
Vasquez-Urriago, A. R., Barge-Gil, A., \& Rico, A. M. (2015). Which firms benefit more from being located in a Science and Technology Park? Empirical evidence for Spain. Research Evaluation, 25(1), 107-117. http s://doi.org/10.1093/reseval/rvv033

Vásquez-Urriago, Á. R., Barge-Gil, A., Rico, A. M., \& Paraskevopoulou, E. (2014). The impact of science and technology parks on firms' product innovation: empirical evidence from Spain. Journal of Evolutionary Economics, 24(4), 835-873. https://doi.org/10.1007/s0 0191-013-0337-1

Vedovello, C. (1997). Science parks and universityindustry interaction: Geographical proximity between the agents as a driving force. Technovation, 17(9), 491-531. https://doi.org/10.1016/S0166-4972(97)000 27-8

Westhead, P. (1997). R\&D “inputs” and “outputs” of technology-based firms located on and off science parks. $R \& D$ Management, 27(1), 45-62. https://doi.or $\mathrm{g} / 10.1111 / 1467-9310.00041$

Westhead, P., \& Batstone, S. (1998). Independent technology-based firms: The perceived benefits of a science park location. Urban Studies, 35(12), 2197-2219. https://doi.org/10.1080/0042098983845

Westhead, P., \& Batstone, S. (1999). Perceived benefits of a managed science park location. Entrepreneurship \& Regional Development, 5626. https://doi.org/10.108 $\underline{0} 089856299283236$

Westhead, P., \& Storey, D. J. (1995). Links between higher education institutions and high technology firms. Omega, 23(4), 345-360. https://doi.org/10.101 6/0305-0483(95)00021-F

Woodside, A. G. (2013). Moving beyond multiple regression analysis to algorithms: Calling for adoption of a paradigm shift from symmetric to asymmetric thinking in data analysis and crafting theory. Journal of Business Research, 66(4), 463-472. $\underline{\mathrm{h}}$ ttps://doi.org/10.1016/j.jbusres.2012.12.021

Wright, M., Liu, X., Buck, T., \& Filatotchev, I. (2008). Returnee Entrepreneurs, Science Park Location Choice and Performance: An Analysis of HighTechnology SMEs in China. Enterp. Theory Pract., 32 (1), 131-155.

Yang, C. H., Motohashi, K., \& Chen, J. R. (2009). Are new technology-based firms located on science parks really more innovative?. Evidence from Taiwan. Research Policy, 38(1), 77-85. https://doi.org/10.1016/ j.respol.2008.09.001 